Submitted 10 Mei 2020

Accepted 18 Juni 2020

\title{
PERANAN SALES SECRETARY DALAM MENDUKUNG KELANCARAN MANAJEMEN SALES DI KUTA PARADISO HOTEL
}

\author{
Ni Luh Supartini ${ }^{1}$ \\ Cendana Cahyani Lestari Guyana ${ }^{2}$ \\ ${ }^{12}$ Institut Pariwisata dan Bisnis Internasional \\ E-mail: supartini@stpbi.ac.id \\ cendanaclg@gmail.com
}

\begin{abstract}
The role of a secretary is required in assiting to complete the whole works. As a secretary, the most important skill is managing time and choosing work priorities so that the main work can be completed on time. At the same time, there are a number of jobs beside of the main jobs should be completed. It affects the load of secretary's jobs were fulled. This study aims to find out how the roles and responsibilities of the sales secretary who are concurrently as sales admins, as well as what are the obstacles faced in carrying out the tasks. Data was collected through observation, interview and documentation techniques. The data analysis technique used in this research is descriptive qualitative. The results of the study showed descriptively that the sales secretary is very instrumental in supporting the management system of sales at Kuta Paradiso Hotel, Bali. The problems was encountered by a secretary was lack of communication skills, lack of human resources that affect the load of secretry's responsibilities was over.
\end{abstract}

Keywords $\quad$ : sales secretary, roles of secretary and management

\section{PENDAHULUAN}

Kuta Paradiso Hotel merupakan hotel berbintang lima yang berlokasi di Jalan Dewi Sartika (Kartika Plaza) Kuta dan dioperasikan mulai tahun 1996. Pemilik Kuta Paradiso Hotel adalah Bapak Harijanto Karjadi. Kuta Paradiso Hotel terdiri dari 257 kamar di mana kamar salable berjumlah 251 kamar. Selain memiliki fasilitas kamar, Kuta Paradiso Hotel memiliki 7 restoran, 1 kolam renang, 1 Spa, 1 Kids Club, 1 Gym, dan 4 Meeting Room. Untuk memastikan semua fasilitas dapat berjalan dengan lancar, Kuta Paradiso Hotel memiliki 9 departemen untuk melancarkan semua aktivitas hotel. Di setiap hotel, memiliki departemen yang berbeda-berbeda namun kadang memiliki fungsi yang sama. Salah satu departemen yang menjadi sorotan di hotel ini adalah Departemen Sales dan Marketing.

Departemen Sales and Marketing merupakan salah satu departemen yang bertugas memasarkan dan bertanggung jawab atas penjualan produk yang dimiliki hotel. Pada dasarnya sales and marketing merupakan suatu hal yang saling berhubungan satu dengan yang lainya, Sales berarti karyawan yang bertugas untuk menjual sedangkan marketing karyawan yang bertugas untuk memasarkan. Sales 
\& Marketing Departemen di Kuta Paradiso Hotel berada di bawah General Manager langsung.

Di Paradiso Hotel, staffnya terdiri dari banyak orang dan masing-masing memiliki tugas yang berbeda-beda tentunya. Seorang Sales Secretary di departemen ini juga merangkap sebagai Sales administrator. Dalam menjalankan tugasnya, seorang sales secretary harus bertanggung jawab terhadap manager di departemennya. Dan disini ada lima manager di bawah Departement Sales dan Marketing.

Pada kenyataannya dari observasi yang peneliti lakukan pada saat melaksanakan management training di section Sales, peneliti menemukan beberapa permasalahan di Sales Department Kuta Paradiso Hotel. Berdasarkan observasi tersebut, peneliti melihat adanya indikasi pemberian tugas yang berlebihan di luar Job Description seorang secretary yang dirangkap sebagai seorang sales admin. Kemudian pengambilan paket belanja online pribadi dan makanan para manajer saat istirahat, pencatatan minute meeting di luar section Sales, serta pembuatan laporan yang harusnya dilakukan oleh manager juga menjadi tanggung jawab Sales Secretary.

Hal tersebut menyebabkan Sales Secretary memiliki beban kerja yang lebih banyak, sehingga masalah seperti kekeliruan rekap absensi staff, keterlambatan pembuatan surat - surat penting, over-time kerja dan keterlambatan pembalasan surat sering terjadi. Dari ulasan tersebut menunjukan adanya indikasi bahwa Sales Secretary memiliki beban kerja melebihi tugas yang telah ditetapkan pada $J o b$ Description sehingga kinerjanya tidak berjalan dengan optimal. Jika hal ini terjadi terus menerus akan berdampak buruk baik kepada Sales Secretary maupun kepada Kuta Paradiso Hotel.

Berdasarkan fenomena yang telah dipaparkan pada latar belakang sebelumnya, dapat dirumuskan dua permasalahan: 1) Apakah peranan dan tugas Sales Secretary yang merangkap sebagai Sales Admin dalam menunjang kelancaran manajemen di Kuta Paradiso Hotel? dan 2) Apakah kendala yang dihadapi seorang Sales Secretary di Kuta Paradiso Hotel?

\section{TINJAUAN PUSTAKA}

Dalam penelitian ini, ada beberapa kajian pustaka yang peneliti gunakan terkait dengan peranan secretary dalam mendukung kelancaran kerja. Seperti penelitian yang dilakukan oleh Suryaniadi (2013) yang berjudul "Peranan Sekretaris Dalam Melancarkan Tugas Perkantoran Di Hotel Melia Bali, Nusa Dua”. Masalah untuk penelitian ini adalah seberapa besar peran seorang sekretaris dalam melakukan pekerjaan kantor di Melia Bali Nusa Dua, dan tujuan dari penelitian ini adalah untuk mengetahui lebih banyak tentang tugas sekretaris dan seberapa banyak dia bisa menyelesaikannya dengan baik.

Selain itu, ada juga penelitian sejenis yang dilakukan oleh Anjarwati (2009) dengan judul "Fungsi Dan Peranan Sekretaris Dalam Membantu Pimpinan Pada Badan Kepegawaian Daerah Kabupaten Demak”. Permasalahan yang dikaji dalam penelitian ini adalah bagaimana fungsi sekretaris di dalam membantu pimpinan di BKD Kab.Demak, bagaimana Peranan sekretaris dalam menunjang kegiatan kantor di BKD Kab.Demak, dan apa saja wewenang sekretaris dalam pelaksanaan pekerjaan kantor di BKD Kab.Demak. Penelitian ini merupakan penelitian kualitatif dengan menggunakan teknik analisis data dekskriptif. Kesimpulan dari 
penelitian ini adalah fungsi dan peranan sekretaris sangat dibutuhkan oleh BKD Kab.Demak karena dapat membantu meringankan tugas terutama Pimpinan.

Penelitian lain yang terkait dengan penelitian ini adalah penelitian yang dilakukan oleh Handayani (2016) yang berjudul "Peranan Sales Administration Section pada Sales and Marketing Department dalam Penyelenggaraan Kegiatan MICE di Lorin Business Resort and SPA Surakarta”. Hasil penelitian menunjukan bahwa Sales Administration Section memegang peranan penting dalam kelancaran sebuah kegiatan MICE yang berkaitan dengan dokumen dokumen yang diperlukan demi kelancaran persiapan penyelenggaraan MICE. Kendala yang dihadapi oleh Sales Administration Section dalam menangani kegiatan MICE berupa kebutuhan pelanggan yang semakin kompleks, dan koordinasi antara staf yang kurang efektif.

Menurut Louis C. Nahassy dan William Selden (2008: 2), secretary adalah: "Asisten atau pegawai kantor yang karena kedudukannya memiliki tanggung jawab yang lebih daripada tanggung jawab seorang stenografer. Tugas-tugasnya biasanya meliputi pengambilan dan penyalinan dikte (menyalin apa yang disampaikan oleh pimpinan ke dalam bentuk tulisan, biasanya yang didiktekan adalah konsep surat) yang berurusan dengan publik, menjawab telepon, mengundang pertemuan, membuat perjanjian, serta memelihara atau mengarsip warkat-warkat dan suratsurat. Seorang sekretaris sering bertindak sebagai seorang pembantu administrasi atau pimpinan muda".

Sedangkan Sales merupakan bagian di suatu perusahaan yang mengurusi bagian penjualan. Sehingga sales secretary adalah orang yang membantu tugas pimpinan di bagian sales (penjualan).

\section{A. Peran Sales Secretary}

Peran Sales Secretary sebagai asisten para manajer mempunyai tanggung jawab langsung atas jalannya kelancaran manajemen di suatu perusahaan. Pada dasarnya setiap sekretaris mempunyai peranan yang sama, yaitu membantu kelancaran pelaksanaan tugas - tugas pimpinan. Dalam melaksanakan tugas tersebut, seorang sekretaris bukan hanya berhubungan dengan pimpinannya saja melainkan juga dengan klien perusahaan, karyawan lain, dan dengan pekerjaan yang ditekuninya.

Adapun peranan sekretaris yang dikemukakan oleh Hartiti dan Tulus Haryono (2003:6) adalah:

"sebagai penjaga atau beranda perusahaan, dalam menerima tamu, sekretaris menyeleksi siapa yang bisa dan tidak bisa bertemu dengan pimpinan, kapan waktunya supaya diatur jadwalnya dan tidak saling bertabrakan. Sebagai filter dan pengelola informasi, surat yang masuk dicatat, diatur, dan diolah terlebih dahulu. Sekretaris mencari, mengolah, menyimpan, mengatur, dan bila diperlukan mencari informasi-informasi yang diperlukan pimpinan."

\section{B. Tugas Sales Secretary}

Sekretaris dibutuhkan oleh pimpinan untuk membantu meringankan tugastugas dan beban pimpinan, terutama dalam tugas-tugas bersifat rutin dan operasional sehingga pimpinan dapat berkonsentrasi dan mengurus tugastugas manajerialnya. Menurut Herlambang dan Marwoto (2014), tugas - tugas seorang sekretaris sebagai berikut:

a. Tugas Rutin

Merupakan tugas umum sehari-hari seorang sekretaris tanpa menunggu intruksi khusus pimpinan, waktu pelaksanaan sesuai job description. 
b. Tugas Instruksi

Merupakan tugas seorang sekretaris yang diperintahkan secara khusus oleh pimpinan tidak tercantum dalam job description.

c. Tugas Kreatif

Merupakan tugas yang dilakukan oleh seorang sekretaris atas prakarsa atau inisiatif sendiri, meringankan beban, menciptakan efisiensi dan efektivitas kerja. Sedangkan tugas seorang sales administrator adalah menangani tugas administratif seperti memasukkan data base dari konsumen setiap sales, monitoring sejauh mana produk siap untuk diserahkan kepada konsumen, membuat report aktifitas sales setiap hari, setiap minggu bahkan setiap bulan.

Dari uraian diatas, dapat disimpulkan bahwa tugas sekretaris dibedakan dalam tiga kelompok, yaitu tugas rutin, tugas instruksi dan tugas kreatif. Semua tugas yang dilakukan bertujuan untuk membantu kerja pimpinan.

\section{Fungsi Sales Secretary}

Seorang sekretaris memiliki fungsi yang sama. Menurut Herlambang dan Marwoto (2014: 9) fungsi sekretaris dibedakan dalam tiga fungsi utama yaitu:

a. Fungsi sekretaris berdasarkan ruang lingkup tugas Sekretaris

Berdasarkan ruang lingkup Sekretaris, fungsi Sekretaris dapat dibagi menjadi dua, yaitu:

1) Fungsi Primer

Fungsi primer seorang sekretaris adalah memberikan jasa administrative penunjang kegiatan operasional organisasi perusahaan atau unit organisasi melalui ketrampilan, meliputi, pengetikan, penanganan telepon, serta pengelolaan surat dan arsip, agenda, penggandaan, dan lain-lain.

2) Fungsi Sekunder

Fungsi sekunder seorang sekretaris adalah ikut menjamin kelancaran kegiatan organisasi atau perusahaan dan bertanggung jawab atas aktivitas rutin kantor, menggunakan pengetahuan bisnis perbankan, statistic, keuanganm hubungan antar manusia, komunikasi, teknik persiapan rapat.

b. Fungsi sekretaris berdasarkan kedudukan sekretaris dalam organisasi

Fungsi sekretaris merupakan seorang staf atau karyawan, resepsionis, operator telepon, pengarsipan dokumen, pengetik, pembantu pimpinan, seorang dan seorang public relation officer.

c. Fungsi sekretaris berdasarkan hubungan Sekretaris dengan pimpinan

Fungsi sekretaris adalah sebagai penjaga manajemen pimpinan, asisten pribadi, perawat dan penasihat. Hubungan sekretaris dan pimpinan sangat dekat dan bersifat professional berkaitan dengan pekerjaan di kantor.

Maka dapat disimpulkan bahwa fungsi sekretaris adalah sebagai pembantu pimpinan dalam mendukung kelancaran kerja pimpinan.

\section{A. Kendala Yang Dihadapi Sales Secretary}

Menurut Anora, dkk (2013) kendala yang dihadapi sekretaris adalah:

a. Kurangnya keterampilan sekretaris dalam berkomunikasi secara efektif.

Seorang sekretaris setiap harinya beerkomunikasi dengan tamu-tamu dengan berbagai tingkatan dan golongan. Untuk itu seorang sekretaris harus 
mampu berkomunikasi dengan baik dan menguasai Bahasa Indonesia dan beberapa bahasa asing dengan baik.

b. Kurangnya kemampuan seorang sekretaris dalam mencari, menginterpretasikan dan memanfaatkan informasi.

Sekretaris bertugas mencarikan dan menyajikan informasi kepada pimpinannya. Untuk itu ia harus pandai menggali informasi dari berbagai sumber, lalu menginterpretasikan sehingga dapat memiih informasi yang di nilai bermanfaat untuk disajikan kepada pemimpin

c. Tingkat berfikir yang kurang dalam mengidentifikasikan masalah dan pencarian solusi.

Sekretaris yang bekerja secara paripurna harus mampu berpikir untuk mengidentifikasi sebab dan akibat setiap kali menghadapi masalah dan dapat mencari solusinya dengan tepat. Sehingga pimpinan tidak perlu terus menerus menuntun dan membimbing sekretaris, namun cukup mendelegasikan setiap penugasan kepada sekretaris dan sekretaris yang bersangkutan mampu menyelesaikannya secara paripurna.

d. Kurangnya kemampuan dalam menangani tugas.

Seseorang yang tidak memiliki komitmen dalam tugasnya hanya menyelesaikan pekerjaan didasari oleh ketaatan pada norma-norma formal yang berlaku, yang mengikat orang untuk melaksanakan tugasnya. Namun apabila pengawasan mengendur atau sangsi tidak diterapkan secara konsisten, maka orang akan cenderung melanggar aturan ataupun menghindari tanggung jawab.

e. Kurangnya kemampuan mengembangkan skill Human Relations.

Kemampuan-kemampuan yang harus dimiliki oleh seorang sekretaris yaitu kemampuan dan keterampilan teknis seperti komputer, Bahasa Inggris, shorthand dan filling, kemampuan berkomunikasi dan berinteraksi, keterampilan penggunaan mesin-mesin kantor. Oleh karena tugas sekretaris adalah berhubungan dengan berbagai macam individu yang masing-masing berbeda latar belakang, berbeda status sosial, berbeda kepentingan, berbeda kedudukan, maka sekretaris dituntut mampu memahami pihak- pihak yang berhubungan dengannya. Hal yang perlu diperhatikan dalam human relation adalah teamwork, posiive thinking, good remainder, Discrete, dan Tacful.

f. Kurangnya tanggung jawab dalam bekerja.

Seorang sekretaris harus memiliki komitmen dan sikap yang dilandasi rasa tanggung jawabpada tugas maka mereka akan menyelesaikan tugas atau pekerjaannya karena merasa terikat pada penyelesaian tugas tersebut, bukan karena terikat pada norma-norma formal, sehingga apabila tidak menyelesaikan tugas dengan sebaik-baiknya, mereka akan merasa bersalah dan bukannya takut pada sanksi.

g. Kurangnya wawasan atau pengetahuan seorang sekretaris.

Pada zaman era globalisasi, sekretaris harus mengembangkan diri mengikuti perkembangan Ilmu pengetahuan dan teknologi. Untuk menjadi sekretaris yang profesional harus dapat mengikuti perkembangan zaman sehingga mampu dapat mengatasi perubahan dan dapat bekerja semaksimal mungkin untuk menghadapi dunia kerja seorang sekretaris dengan daya saing yang semakin maju 


\section{HASIL DAN PEMBAHASAN}

Pada hasil penelitian ini, peneliti memaparkan hasil penelitian berdasarkan sebagaimana adanya yang terjadi di lapangan, yang dialami, dirasakan dan dipikirkan oleh peneliti. Peneliti menjabarkan hasil observasi berdasarkan teori teori peranan sekretaris dan fungsi-fungsi manajemen Sales Secretary serta hasil wawancara dengan seorang Sales Manager dan seorang Sales Secretary di Kuta Paradiso Hotel. Dari hasil penelitian yang diperoleh, maka didapat hasil dan pembahasan mengenai peranan Sales Secretary dan kendala yang dihadapi oleh sales secretary sebagai berikut:

Tugas yang dilakukan oleh Sales Secretary dalam job description merupakan implementasi dari fungsi-fungsi manajemen seperti:

a. Fungsi Perencanaan

Menurut Terry (2010) Planning (perencanaan) ialah penetapan pekerjaan yang harus dilaksanakan oleh kelompok untuk mencapai tujuan yang digariskan. Dari teori tersebut jika dikaitkan dengan hasil observasi yang didapat, yaitu perencanaan yang dilakukan oleh sekretaris / administrator terlihat pada bagaimana ia membuat laporan, membuat check list tugas yang ada pada jobdesc, mencatat dan mendistribusikan segala bentuk informasi yang didapat, membuat payment request, serta memberikan saran dan ide kepada pimpinan. Semua dilakukan dengan baik dan benar sehingga kegiatan di sales berjalan lancar. Kemudian hasil wawancara dengan sales secretary/sales admin dan sales manager yang mengatakan:

"Saya membantu membuat minute sales meeting, membuat payment request, membuat budget sales, membuat jadwal kerja sales staf, membuat invitation, memo dan guest list jika ada event, dan masih banyak lagi sesuai dengan jobdesc yang ada." (Mrs. Ladys Apriliani, selaku sales secretary).

Mrs. Ayu Ningrat selaku sales manager menambahkan:

"Sekretaris sangat membantu membuat minute sales meeting, membuat payment request, membuat budget sales, membuat complimentary stay, membuat jadwal kerja sales staf, membuat invitation, memo dan guest list jika ada event, membuat memo komisi dan semua tugas yang ada pada jobdesc. Semua dilakukan dengan baik dan benar sehingga kegiatan di sales berjalan lancar."

Maka dapat disimpulkan bahwa tugas yang dilakukan oleh sales secretary yang merangkap sebagai sales admin dalam fungsi perencanaan kegiatan manajemen meliputi membuat minute sales meeting, membuat payment request, membuat budget sales, membuat jadwal kerja sales staf, membuat invitation, memo dan guest list jika ada event, membuat complimentary stay, membuat laporan, membuat check list tugas yang ada pada jobdesc, mencatat dan mendistribusikan segala bentuk informasi yang didapat, serta memberikan saran dan ide kepada pimpinan.

b. Fungsi Pengorganisasian

Menurut Terry (2010) pengorganisasian adalah proses pengelompokan kegiatan - kegiatan untuk mencapai tujuan-tujuan dan penugasan setiap kelompok kepada seorang manajer. Dari teori tersebut jika dikaitkan dengan data hasil observasi, yaitu pengorganisasian yang dilakukan oleh sekretaris terlihat pada bagaimana ia mampu mengorganisir tugas dengan baik, yang mana yang harus didahulukan, kapan harus dikerjakan sehingga pengerjaan tugas menjadi efektif dan 
efisien, seperti mengatur trainee, mengatur pertemuan pimpinan dengan klien, menangani petty cash, menyiapkan segala kebutuhan perjalanan bisnis pimpinan, memberikan motivasi, saran dan ide agar kegiatan manajemen di sales berjalan dengan lancar. Serta hasil wawancara dengan sales secretary dan sales manager seperti sebagai berikut:

"Saya membantu menyiapkan morning briefing, menyiapkan banyak hal sesuai job description. Saya mengorganisir pekerjaan seefektif dan seefisien mungkin guna melancarkan kegiatan manajemen di Sales." (Mrs. Ladys Apriliani, selaku sales secretary)

"Sekretaris mampu mengorganisir tugas dengan baik, yang mana yang harus didahulukan, kapan harus dikerjakan sehingga pengerjaan tugas menjadi efektif dan efisien." (Mrs. Ayu Ningrat, selaku sales manager)

Berdasarkan hasil observasi dan wawanacara yang dilakukan, serta dikaitkan dengan teori yang ada, dapat disimpulkan pengorganisasian tugas yang dilakukan oleh sales secretary yang merangkap sebagai sales admin dalam fungsi perencanaan kegiatan manajemen meliputi mengatur trainee, mengatur pertemuan pimpinan dengan klien, menangani petty cash, memberikan motivasi, saran dan ide, menyiapkan morning briefing, serta menyiapkan segala kebutuhan perjalanan bisnis pimpinan.

c. Fungsi Penerapan

Menurut Terry (2010) penerapan merupakan usaha menggerakkan anggotaanggota kelompok sedemikian rupa, hingga mereka berkeinginan dan berusaha untuk mencapai tujuan yang telah direncanakan bersama. Jika dikaitkan dengan data hasil observasi yaitu penerapan tugas yang dilakukan sekretaris terlihat dari bagaimana ia mengerjakan semua tugas dan fungsi sebagai seorang sales secretary dan sebagai sales admin dengan baik, benar, sesuai harapan serta penerapan tugas dan planning yang dibuat sangat detil, menjalin hubungan yang baik dengan pimpinan, klien dan staf,mengetahui dengan pasti semua informasi tentang hotel khususnya pada bagian sales dan segala bentuk kebijakan yang dimiliki oleh hotel, menangani petty cash, memberikan motivasi, saran dan ide, sehingga mendukung kelancaran kegiatan di sales.

Adapun hasil wawancara dengan sales secretary/sales admin dan sales manager adalah sebagai berikut:

"Saya menerapkan semua perencanaan tersebut dengan detil dan benar. Memastikan semuanya berjalan sesuai dengan harapan" (Mrs. Ladys Apriliani, selaku sales secretary/sales admin)

"Semua tugas dan fungsi sebagai seorang sales secretary telah dilaksanakan dengan baik dan benar, serta sesuai harapan. Penerapan tugas dan planning yang dibuat sangat detil dan mendukung kelancaran kegiatan di sales." (Mrs. Ayu Ningrat, selaku sales manager)

Berdasarkan hasil observasi dan wawanacara yang dilakukan, dapat disimpulkan pengorganisasian tugas yang dilakukan secara detil dan benar oleh sales secretary/sales admin sangat mendukung kelancaran kegiatan manajemen di sales. 


\section{d. Fungsi Pengawasan}

Menurut Terry (2010) pengawasan merupakan penemuan dan penerapan cara dan alat utk menjamin bahwa rencana telah dilaksanakan sesuai dengan rencana yang telah ditetapkan. Jika dikaitkan dengan data hasil observasi, dapat dipaparkan bahwa pengawasan yang dilakukan oleh sales secretary yang merangkap sebagai sales admin terlihat dari bagaimana ia sangat teliti dalam memastikan semua kegiatan berjalan lancar. Mengawasi pekerjaan yang dilakukan oleh trainee, memastikan semua alat dan mesin tetap pada kondisi yang baik. Memastikan air galon selalu isi dan memastikan semua peralatan dan mesin telah tersimpan rapi dan dalam keadaan mati saat jam pulang kerja tiba, memastikan tidak ada miss communication dengan pimpinan serta memastikan pimpinan mengerjakan tugas mereka tepat waktu.

Adapun data hasil wawancara dengan sales secretary dan sales manager yang mempertegas hasil observasi di atas adalah sebagai berikut:

"Saya mengingatkan kembali tugas - tugas yang belum diselesaikan oleh pimpinan, kemudian membuat check list pekerjaan yang harus saya lakukan serta memeriksa semua alat dan mesin yang ada di sales tetap dalam kondisi yang baik" (Mrs. Ladys Apriliani, selaku sales secretary)

"Sekretaris sangat teliti dalam memastikan semua kegiatan berjalan lancar.

Memastikan semua alat dan mesin tetap pada kondisi yang baik." (Mrs. Ayu

Ningrat, selaku sales manager)

Berdasarkan hasil observasi dan wawancara yang dilakukan, dapat disimpulkan bahwa sales secretary yang merangkap sebagai sales admin sangat mendukung kelancaran kegiatan manajemen di sales dengan memastikan segala sesuatunya berjalan dengan baik dan lancar dengan mengawasi pekerjaan yang dilakukan oleh trainee, memastikan semua alat dan mesin tetap pada kondisi yang baik. Memastikan air galon selalu isi dan memastikan semua peralatan dan mesin telah tersimpan rapi dan dalam keadaan mati saat jam pulang kerja tiba, memastikan tidak ada miscommunication dengan pimpinan serta memastikan pimpinan mengerjakan tugas mereka tepat waktu.

\section{A. Peranan dan Tugas Sales Secretary dan Sales Admin}

Berdasarkan teori peranan sales secretary, pemaparan tugas yang dimiliki oleh sales secretary/sales admin dalam fungsi - fungsi manajemen yang ada, hasil observasi dan wawancara, maka didapat peranan dan tugas sales secretary yang merangkap sebagai sales admin seperti:

a. Sekretaris sebagai Asisten Administrasi

Peranan sekretaris di hotel selain membantu kelancaran tugas pimpinan, juga sebagai asisten administrasi. Dalam hal ini, tugas sekretaris adalah menyiapkan kontrak dengan travel agent, membuat presentasi, menyiapkan berkas - berkas meeting, menyiapkan 3 month forecast, Competitor Statistic, Nationality Statistic Report, Expected Arrival Guest-VIP, Minutes of Daily Morning Briefing.

b. Sekretaris sebagai Penghubung / Humas

Sebagai penghubung / humas, sekretaris berperan sebagai jembatan penghubung antara pimpinan, klien dan karyawan lainnya. Sekretaris berwenang dalam memutuskan apakah klien yang ingin bertemu dengan pimpinan diperbolehkan untuk bertemu dengan pimpinan. Sekretaris juga 
diharapkan mampu berkomunikasi dengan baik sehingga hubungan dengan pihak manapun dapat terjalin dengan baik.

c. Sekretaris sebagai Pengelola Informasi

Selain peran di atas, sekretaris juga berperan sebagai pengelola informasi. Sekretaris harus mengetahui dan memahami segala bentuk informasi mengenai hotel khususnya di sales section. Informasi yang didapat melalui email akan langsung diteruskan kepada pihak yang terkait. Informasi melalui telepon akan dicatat di sticky note atau langsung disambungkan kepada telepon pihak terkait, sehingga informasi yang didapat tidak sampai terlupakan dan menyebabkan kesalahpahaman.

d. Sekretaris sebagai Bendahara

Sebagai bendahara, sekretaris menangani uang kas yang digunakan untuk keperluan mendadak seperti pembelian barang yang tidak ada di store, atau pembelian hadiah untuk klien. Selain itu sekretaris menangani pembuatan payment request kepada accounting untuk me-refund uang perjalanan bisnis (sales trip), bensin kendaraan yang digunakan untuk urusan pekerjaan seperti melakukan sales call. Kemudian membuat payment request untuk uang makan bagi staf yang tidak makan di hotel karena urusan pekerjaan dan harus makan di luar hotel.

e. Sekretaris sebagai Pemberi Motivasi

Sebagai pemberi motivasi, sekretaris diharapkan mampu memberi motivasi dan dorongan positif kepada pimpinan dan karyawan lainnya, dengan tujuan melancarkan segala bentuk kegiatan manajemen di sales. Dalam hal ini, sekretaris memotivasi dengan mengingatkan kembali pimpinan akan tugas yang belum diselesaikan dan mengingatkan target yang harus dicapai guna memastikan kelancaran kegiatan manajemen tetap terjaga.

f. Sekretaris sebagai Pemberi Saran / Ide.

Sekretaris sebagai pemberi saran / ide, dalam hal ini sekretaris memiliki karakter yang kreatif dan diharapkan memiliki pengalaman yang banyak sehingga jika sekretaris dimintai pendapat atau ide, sekretaris mampu memberikan saran dan ide yang baik, seperti membuat kejutan ulang tahun bagi karyawan lain.

Selain peranan di atas, tugas lain sekretaris adalah meng-handling telepon masuk dan keluar. Adapun telepon masuk dari luar maupun dari dalam hotel dibedakan berdasarkan jumlah deringan telepon. Sekretaris harus tanggap mengangkat telepon jika karyawan lain tidak mengangkat telepon dan memastikan mengangkat sebelum telepon berdering lebih dari tiga kali. Informasi yang didapat melalui telepon juga harus dicatat agar tidak terlupakan.

Tugas lain sekretaris adalah meng-update data base klien agar tidak kehilangan kontak. Menangani filling, seperti filling contract rate, purchase request, complimentary form serta menangani email masuk dan keluar. Menyiapkan contract rate yang biasanya dibedakan menjadi dua yaitu harga untuk active agent dan non-active agent. Berkoordinasi dengan pihak housekeeping jika ada site inspection. Site Inspection biasanya dilakukan oleh agen yang ingin membawa tamu untuk menginap untuk melihat kondisi kamar.

Membuat jadwal kerja juga merupakan tugas dari seorang sekretaris. Sekretaris bertugas meng-update jadwal kerja karyawan dan mengurus leave form, 
surat sakit, formulir cuti dan libur yang akan diserahkan kepada bagian HRD di awal bulan.

Selain itu sekretaris juga bertugas menyiapkan perjalanan bisnis pimpinan seperti sales kit dan name card, serta hotel voucher. Kemudian membuat travel expense report yang merupakan laporan perincian biaya yang dikeluarkan selama melakukan perjalanan bisnis.

Mengecek perlengkapan alat tulis kantor serta memastikan semua alat dan mesin berada pada kondisi yang baik dan layak pakai juga merupakan tugas dari sekretaris. Membuat beverage store requisition jika air mineral untuk karyawan habis serta menyiapkan maintenance order form jika ada mesin atau alat yang perlu diperbaiki.

Berdasarkan penjelasan diatas, dapat diambil kesimpulan bahwa sales secretary memiliki peranan dan tugas yang sangat penting dalam mendukung kelancaran kegiatan manajemen sales di Kuta Paradiso Hotel.

\section{B. Kendala yang dihadapi}

Menurut Anora, dkk (2013) kendala yang dihadapi seorang sekretaris antara lain:

1. Kurangnya keterampilan sekretaris dalam berkomunikasi secara efektif.

2. Kurangnya kemampuan seorang sekretaris dalam mencari, menginterpretasikan dan memanfaatkan informasi.

3. Tingkat berfikir yang kurang dalam mengidentifikasikan masalah dan pencarian solusi.

4. Kurangnya kemampuan dalam menangani tugas.

5. Kurangnya kemampuan mengembangkan skill Human Relations

6. Kurangnya tanggung jawab dalam bekerja

7. Kurangnya wawasan atau pengetahuan seorang sekretaris

Berdasarkan teori kendala yang dihadapi sekretaris tersebut, jika dikaitkan dengan hasil observasi dan wawancara, maka didapat kendala-kendala yang dihadapi oleh sales secretary seperti:

a. Pemberian tugas yang berlebihan di luar job desc sebagai sales secretary, sehingga tugas pokok di dalam jobdesc terkadang terlambat diselesaikan.

Sekretaris memiliki beban kerja yang berlebih seperti harus menyelesaikan tugas- tugas yang seharusnya dilakukan oleh sales admin, harus dikerjakan sendiri. Kemudian pengerjaan laporan harian dan bulanan yang seharusnya dikerjakan sendiri oleh pimpinan harus dikerjakan oleh sekretaris. Pengambilan makanan di saat jam istirahat di kantin menjadi tugas rutin yang harus dilakukan. Pengambilan paket belanja online di luar area hotel serta pembuatan risalah rapat diluar sales section juga menjadi tanggung jawab sales secretary. Pengerjaan tugas diluar sales section sering kali dianggap sebagai hal yang wajar dan dimanfaatkan banyak pihak untuk kepentingan section masing-masing.

b. Kurangnya sumber daya manusia untuk membantu sekretaris

Berdasarkan data hasil wawancara, didapat hasil bahwa sekretaris harus membantu menyelesaikan tugas-tugas yang diberikan oleh section lainnya seperti marketing section dan reservation section. Hal ini disebabkan karena section - section tersebut tidak memiliki sekretaris khusus seperti yang ada di sales setion, sehingga keberadaan sales secretary yang berada dalam satu ruangan dengan section lain mengharuskan sales secretary membantu 
menyelesaikan tugas yang diberikan section lain. Kemudian kosongnya posisi sebagai sales admin menyebabkan sales secretary harus mengambil alih semua pekerjaan sales admin. Jarangnya mendapat trainee untuk membantu kinerja sales secretary juga menjadi kendala bagi sekretaris untuk menyelesaikan tugasnya.

c. Kurangnya kemampuan dalam berkomunikasi

Berdasarkan hasil observasi yang peneliti dapatkan, sekretaris mampu berkomunikasi dengan baik dan benar jika menggunakan Bahasa Indonesia. Namun, dalam penggunaan bahasa asing, khususnya bahasa Inggris, sekretaris masih belum bisa berkomunikasi dengan baik dan lancar. Hal ini menjadi kendala bagi sekretaris apabila menerima telepon atau bertemu langsung dengan tamu asing.

Berdasarkan pemaparan hasil penelitian diatas, dapat disimpulkan bahwa kendala yang dihadapi sales secretary di Kuta Paradiso Hotel adalah beban pekerjaan yang berlebih, kurangnya sumber daya untuk membantu sales secretary dan kurangnya kemampuan berkomunikasi dalam bahasa asing oleh sales secretary.

Selain itu, berdasarkan observasi yang peneliti lakukan, peneliti menemukan sudut pandang yang berbeda dari pekerjaan seorang sekretaris. Seorang sekretaris tidak hanya bertugas untuk mendukung kelancaran kerja suatu organisasi maupun hanya bertugas mengurusi urusan administrasi saja. Pekerjaan seorang sekretaris memiliki peranan yang besar dalam kelancaran suatu organisasi. Sekretaris bertanggungjawab atas citra positif perusahaan dan citra positif pimpinan karena sekretaris merupakan pihak pertama yang menjadi penghubung antara pimpinan dengan klien.

Peneliti juga melihat bahwa pekerjaan seorang sekretaris merupakan pekerjaan yang tidak mudah karena seorang sekretaris dituntut untuk dapat bekerja secara multitasking dan pekerjaan sebagai sekretaris masih sering mendapat anggapan yang kurang baik dari masyarakat karena dipandang sebagai simpanan pimpinan. Pendapat ini timbul karena ketidaktahuan masyarakat tentang bagaimana pekerjaan seorang sekretaris sebenarnya. Pekerjaan menjadi sekretaris memang sangat menjanjikan, namun dalam praktek sehari-hari pekerjaan sekretaris adalah pekerjaan serabutan yang mengharuskan sekretaris memiliki sikap yang cekatan serta kemampuan, pengetahuan dan kepribadian yang mumpuni.

\section{PENUTUP}

\section{A. Simpulan}

Berdasarkan rumusan masalah pada skripsi ini, dapat disimpulkan bahwa:

a. Peranan Sales Secretary yang merangkap sebagai Sales Admin adalah sebagai asisten adminitrasi, sebagai penghubung / humas, sebagai pengelola informasi, sebagai bendahara, sebagai pemberi motivasi dan sebagai pemberi saran dan ide. Tugas yang dimiliki Sales Secretary meliputi tugas rutin seperti tugas - tugas yang telah ditetapkan dalam job description atau tugas - tugas administrative. Selain itu, tugas instruksi seperti tugas - tugas di luar job description yang diberikan secara langsung oleh pimpinan, dan tugas kreatif yang merupakan pengerjaan tugas berdasarkan inisiatif dan kreativitas dari sekretaris seperti pengembangan diri dengan cara mencari tahu informasi lebih dalam mengenai suatu hal. 
b. Kendala yang dihadapi sekretaris

Kendala yang dihadapi sebagai seorang sekretaris antara lain pemberian tugas yang berlebihan sehingga tugas pokok sebagai sales secretary terkadang menjadi terlambat diselesaikan, kurangnya sumber daya manusia untuk membantu sekretaris dalam penyelesaian tugas dan kurangnya kemampuan dalam berkomunikasi.

\section{B. Saran}

Seorang sekretaris diharapkam mampu bekerja secara efektif dan efisien serta mampu memiliki karakter yang kreatif, tanggap, dan cekatan. Selain itu sekretaris diharapkan memiliki psikologis yang kuat dan selalu berpikir positif, serta memiliki kemampuan kesekretariatan, mampu berpikir logis, berinisiatif, mengikuti perkembangan masalah dan selalu meningkatkan wawasan.

Sekretaris juga diharapkan mampu mengikuti perubahan dan perkembangan di tempat kerja sehingga penyelesaian tugas tidak terhambat. Selalu belajar dari kesalahan dan berusaha mengenal sifat dan karakter pimpinan serta menjadi panutan bagi pimpinan dalam mengerjakan suatu hal.

\section{DAFTAR PUSTAKA}

Abdullah Ma'ruf. 2014. Manajemen dan Evaluasi Kinerja Karyawan. Yogyakarta: Aswaja Pressindo

Agus Sulastiyono. 2011. Manajemen Penyelenggaraan Hotel. Bandung: Manajemen Hotel Bandung

Anjarwati. 2009. Fungsi Dan Peranan Sekretaris Dalam Membantu Pimpinan

Pada Badan Kepegawaian Daerah Kabupaten Demak. Available from:

URL: https://lib.unnes.ac.id/2413/1/6239.pdf

Anora, dkk. 2013. Makalah Tugas, Kualifikasi dan Masalah Yang Dihadapi

Sekretaris. Available from URL: https://www.academia.edu/

8541433/makalah_tugas_kualifikasi_dan_masalah_yang_dihadapi_sekreta ris

Burhan Bungin. 2011. Penelitian Kualitatif. Jakarta: Kencana Predana Media

Dantes. 2012. Metode Penelitian. Yogyakarta: ANDI

Departemen Pendidikan Nasional. 2002. Kamus Besar Bahasa Indonesia.

Jakarta: Balai Pustaka.

Handayani. 2016. Peranan Sales Administration Section pada Sales and

Marketing Department dalam Penyelenggaraan Kegiatan MICE di Lorin

Business Resort and SPA Surakarta.

Hani Handoko. 2016. Manajemen. Yogyakarta: BPFE

Hartiti dan Tulus Haryono. 2003. Menjadi Sekretaris Profesional. Jakarta: PPM

Hasibuan, M.S.P. 2013. Manajemen Sumber Daya Manusia. Jakarta: PT. Bumi

Aksara

Herlambang dan Marwoto. 2014. Manajemen Kesekretarisatan. Yogyakarta:

Gosyen Pusblishing

Kotler, Philip and Gary Armstrong. 2012. Prinsip-prinsip Pemasaran. Jakarta:

Erlangga

Miles, Mathew B, dan Huberman, A Michael. 1992. Analisis Data Kualitatif.

(Tjetjep Rohendi Rahan, Pentj). Jakarta: UI 
Nahassy dan William Selden. 2008. Business Dictionary. Available from URL: https://www.pelajaran.co.id/2018/15/pengertian-sekretaris-tugas-fungsitujuan-dan jenisnya.html

Nitisemito. 1992. Manajemen dan Sumber Daya Manusia. Yogyakarta: BPFE UGM

Pantiyasa, 2013, Metode Penelitian Yogyakarta Andi

Pantiyasa, 2015, The Effects of Economic, Socio-Cultural and Environment of an Integrated Rural Tourism Destination Pinge Village-Tabanan Vol 1, No 1 (2015)

Robbins, P.Stephen dan Coulter, Mary. 2012. Management. England: PT Pearson Education Limited

Sihite, R. 1996. Tourism Industry. SIC: Surabaya

Soekanto. 2009. Peranan Sosiologi Suatu Pengantar, Edisi Baru. Jakarta: Rajawali Pers

Subagyo. 2011. Available from URL: https://elib.unikom.ac.id/files/ disk1/717/jbptunikompp-gdl-seniyulyan-35824-7-unikom_s-i.pdf

Sugiyono. 2015. Metode Penelitian \& Pengembangan Research and Developmen. Bandung: Alfabeta

Suharsimi Arikunto. 2013. Manajemen Penelitian. Jakarta: PT Rineka Cipta Terry, George dan Lesslie W, Rue. 2010. Dasar-Dasar Manajemen. Cetakan Kesebelas. Jakarta: PT. Bumi Aksara

Suryaniadi, S. M. 2013. Peranan Sekretaris Dalam Melancarkan Tugas Perkantoran Di Hotel Melia Bali, Nusa Du Available from URL: http://scholar.google.co.id/citations?user =wvnR4gsAAAAJ\&hl=en 